\title{
RUSSIAN POLITICAL MASONRY AND THE FEBRUARY REVOLUTION OF 1917
}

Few problems in modern Russian history are more complex or more bewildering than that of political Masonry (politicheskoe masonstvo) ${ }^{\mathbf{1}}$ and its contribution to early-twentieth-century oppositional politics. A decade and a half ago Nathan Smith observed that "Available firsthand evidence about the [political Masonic] movement [...] is incredibly limited and raises as many questions as it answers." 2 That observation is still valid as the origins, structure, composition and activities of the conspiratorial political Masonic organization remain among the best-kept secrets of Russia's past. Indeed, political Masonry was first mentioned in the historiography on the February Revolution only in the early 1930's. ${ }^{3}$ Then, for nearly three decades, scholars simply ignored the problem altogether. This was partially due to a paucity of sources; but equally important was the fact that the subject conjured up images of that pernicious Jewish-Masonicconspiracy theory so popular among right-wing émigré circles. ${ }^{4}$ During the 1960's historians once again turned their attention to political Masonry, although infrequently and usually only in passing. ${ }^{5}$ Since that time a

1 On the distinction between political Masonry and Freemasonry see below, pp. $245 f$.

2 N. Smith, "The Role of Russian Freemasonry in the February Revolution: Another Scrap of Evidence", in: Slavic Review, XXVII (1968), p. 604.

3 The émigré socialist historian S. P. Mel'gunov was the first to raise the issue in a series of articles in the newspaper Za Svobodu (New York), in 1930. These articles subsequently appeared in book form as $\mathrm{Na}$ putiakh $\mathrm{k}$ dvortsovomu perevorotu (Paris, 1931), see especially pp. $9,180-98$.

4 On the origin of the Jewish-Masonic-conspiracy theory see J. Katz, Jews and Freemasons in Europe, 1723-1939 (Cambridge, Mass., 1970), pp. 148-49, 152, 164, 170.

5 The resurgence of scholarly interest in the subject was spurred largely by the appearance in 1959, in Novoe Russkoe Slovo (New York), of several articles by the émigré Menshevik G. Ia. Aronson. These articles were subsequently published, with supplements, in his Rossiia nakanune revoliutsii: Istoricheskie etiudy (New York, 1962), pp. 109-143. The historiography on political Masonry from the 1960's includes S. V. Utechin, Russian Political Thought: A Concise History (London, 1964), pp. 110-11, 195, 207; L. Haimson, "The Problem of Social Stability in Urban Russia, 1905-1917", in: Slavic Review, XXIV (1965), pp. 13-17; G. Katkov, Russia 1917: The February Revo- 
number of treatments have appeared, yet none takes account of all the available evidence. ${ }^{6}$ Moreover, many historians continue to reject out of hand all efforts to deal with political Masonry, dismissing them as attempts to perpetuate the Jewish-Masonic-conspiracy myth, ${ }^{7}$ while other scholars reject the suggestion that the political Masonic organization played a crucial role in the overthrow of the Russian Monarchy and the establishment of the Provisional Government in $1917 .^{\circ}$

The controversy and neglect which characterize the historiography on political Masonry are due in large part, as already indicated, to the absence of any substantial source base. Contemporary sources are limited both in the quantity and in the quality of the evidence they yield. The Masons themselves kept no written records and, bound by an oath of silence, revealed their existence to few outside their own circles. ${ }^{9}$ In contrast to

lution (New York, 1967), pp. 163-73, 378-79, 380, 382, 383; W. Laqueur, The Fate of the Revolution: Interpretations of Soviet History (New York, 1967), pp. 39-40; M. Ferro, La Révolution de 1917: La chute du tsarisme et les origines d'Octobre (2 vols; Paris, 1967), I, p. 236; L. Schapiro, "The Political Thought of the First Provisional Government", in: Revolutionary Russia, ed. by R. Pipes (Cambridge, Mass., 1968), p. 100; Smith, "The Role of Russian Freemasonry", loc. cit.

${ }^{6}$ See V. Kobylin, Imperator Nikolai Il i General-ad"iutant M. V. Alekseev (New York, 1970), pp. 248-51; G. B. Hosking, The Russian Constitutional Experiment: Government and Duma, 1907-1914 (Cambridge, 1973), pp. 196-97; N. N. Iakovlev, 1 avgusta 1914 (Moscow, 1974), pp. 4-18, 154-85 passim, 218-22, 226, 229-35; W. G. Rosenberg, Liberals in the Russian Revolution: The Constitutional Democratic Party, 1917-1921 (Princeton. 1974), pp. 33, note, 58, 78; E. D. Chermenskii, IV Gosudarstvennaia duma i sverzhenie tsarizma v Rossii (Moscow, 1976), pp. 8-9; R. Pearson, The Russian Moderates and the Crisis of Tsarism, 1914-1917 (New York, 1977), pp. 128-29, 172; B. F. Livchak, "O politicheskoi roli masonov vo vtoroi russkoi revoliutsii", in: Mezhvuzovskii Sbornik Nauchnykh Trudov (Sverdlovsk), LVI (1977), pp. 135-41; M. K. Kasvinov, Dvadtsat' tri stupeni vniz (Moscow, 1978), pp. 303-05; V. I. Startsev, Revoliutsiia i vlast': Petrogradskii sovet i vremennoe pravitel'stvo v marte-aprele 1917 g. (Moscow, 1978), pp. 205-07; G. Katkov, Russia 1917: The Kornilov Affair: Kerensky and the Break-up of the Russian Army (London, 1980), pp. 57-59; I. I. Mints, "Metamorfozy masonskoi legendy", in: Istoriia SSSR, 1980, No 4, pp. 107-22; T. Hasegawa, The February Revolution: Petrograd, 1917 (Seattle, 1981), pp. 137, 192-97, 508, 527-29, 547, 556-57; N. Smith, "Masonic Movement in Russia after 1905", in: The Modern Encyclopedia of Russian and Soviet History, XXI (1981), pp. 128-33; V. I. Startsev, Krakh kerenshchiny (Leningrad, 1982), pp. $35,53,55-56$.

For example, see D. T. Orlovsky's review of Startsev, Revoliutsiia i vlast', op. cit., in Kritika, XVI (1980), pp. 124-25.

${ }^{8}$ This is as true of Western as of Soviet historians. See, for example, Hasegawa, The February Revolution, op. cit., pp. 193-96; Mints, "Metamorfozy masonskoi legendy", loc. cit., p. 121.

${ }^{9}$ Upon entering the organization, members were sworn to secrecy; and, according to one prominent Mason, "it was forbidden by the statutes to write down anything, to have documents". E. D. Kuskova to L. O. Dan, November 14, 1958, Dan Archive XVI/14, Internationaal Instituut voor Sociale Geschiedenis. 
most other oppositional groups in this period, the political Masonic organization managed to remain hidden from the ever vigilant Okhrana (political police); hence available police reports contain only indirect evidence. ${ }^{10}$ It is the reminiscences of a few former Masons and several of their contemporaries, therefore, which provide the bulk of the information about political Masonry.

Although the Masons maintained the strictest secrecy about their organization even after most of its leading members had emigrated in the years following the October Revolution, ${ }^{11}$ a few of them did break their silence, if only briefly. Among the first to do so were the émigré Mensheviks N. S. Chkheidze and A. Ia. Gal'pern, who provided the Menshevik historian B. I. Nikolaevskii with information about political Masonry in interviews conducted during the early 1920 's. ${ }^{12}$ E. D. Kuskova, a non-party socialist and prominent journalist both in Russia and in emigration, also noted a number of details about the organization in letters written to friends between the mid 1920's and the late 1950's. ${ }^{13}$ Two former Kadets (members of the Constitutional Democratic Party), Prince V. A. Obolenskii in emigration and N. V. Nekrasov in Soviet Russia, recorded their recollections about political Masonry during the 1930's, as apparently

10 See A. Kerensky, Russia and History's Turning Point (New York, 1965), p. 89. That the organization remained undetected was no mean feat, for the police made numerous efforts in the years before 1917 to uncover any kind of Masonic connections among Russia's oppositional groups. On these efforts see Padenie tsarskogo rezhima ( 7 vols; Moscow, Leningrad, 1924-27), III, pp. 332-34: S. P. Mel'gunov, Vospominaniia i dnevniki (2 vols; Paris, 1964), I, pp. 144-45; id., Na putiakh k dvortsovomu perevorotu, op. cit., p. 182; Istochnikovedenie istorii SSSR XIX - nachala XX v., ed. by I. A. Fedosov et al. (Moscow, 1970), pp. 226-27.

11 On several occasions Kuskova reiterated that the main reason for the Masons' continued silence was the desire to protect former colleagues still in the Soviet Union. Kuskova to N. V. Vol'skii, November 10, 1955, Volsky Collection 5, Hoover Institution, Stanford University; id. to Dan, February 6 and 14, 1956, Dan Archive XV/12.

12 These materials, part of the Nicolaevsky Collection, Hoover Institution, are not generally accessible to scholars. However, a summary of some of the evidence in them is provided in Haimson, "The Problem of Social Stability", loc. cit., pp. 13-14. References to the interviews are also found in Nikolaevskii's letters to Vol'skii from the 1960's in the Volsky Collection 6.

13 Kuskova's letters to L. O. Dan, widow of the Menshevik leader F. I. Dan, are preserved in the Dan Archive XII-XVII; those to Vol'skii and R. A. Abramovich are in the Volsky Collection 5 and in the Nicolaevsky Collection, respectively. A letter to Mel'gunov is reproduced in id., Na putiakh $k$ dvortsovomu perevorotu, pp. 171-72. Two of Kuskova's letters to Dan (from January 20 and February 12, 1957) and one to Vol'skii (from November 10, 1955) are published in Aronson, Rossiia nakanune revoliutsii, op. cit., pp. 138-40. However, since the texts of the three letters have been altered slightly (and the letter to Vol'skii is erroneously dated November 15), all references to Kuskova's letters to Dan and Vol'skii are to the originals. 
did L. P. Velikhov, who remained in Russia. ${ }^{14}$ Finally, A. F. Kerenskii, a former Trudovik (Labor Group member) and head of the Provisional Government, who once served as executive secretary for the political Masonic organization, talked about Masonry with historian S. V. Utechin in the early 1960's. Some of Kerenskii's observations on the subject were included in the memoirs which Utechin helped him prepare for publication. ${ }^{15}$

Yet, like all reminiscences composed years after the events described, the recollections of these former Masons reflect the vagaries of time and memory, as well as occasional efforts at obfuscation. Moreover, these sources are silent on a number of important matters. Similarly brief and reticent are the reminiscences of contemporaries who were aware of the existence of political Masonry either before 1917 or who learned something about it shortly thereafter. These include the recollections of the Kadet V. D. Nabokov from 1918; of the Popular Socialist S. P. Mel'gunov, which were composed in 1920; of the Bolshevik V. D. Bonch-Bruevich and of V. I. Gessen, a former Kadet, which were published during the 1930's; and of another former Kadet, P. N. Miliukov, from the early 1940 's. ${ }^{16}$ Yet, despite the unsatisfactory source base, sufficient direct and indirect evidence is available to reconstruct, at least tentatively, the origins, structure, composition and activities of the political Masonic organization, and to suggest the nature of its contribution to Russian oppositional politics in the early years of the twentieth century.

The origins of Russian political Masonry remain obscure. Historians have traditionally dated its appearance to the second decade of the twentieth

14 An extract from Obolenskii's unpublished memoirs, "Moia zhizn' i moi sovremenniki", is quoted in Smith, "The Role of Russian Freemasonry", pp. 606-08. Nekrasov's unpublished recollections are quoted in Iakovlev, 1 avgusta 1914, op. cit., pp. 230-32, and a brief statement by Velikhov (could it be P. A. Velikhov?) is quoted on p. 234. While Iakovlev does not identify the specific sources utilized, there seems to be no reason to doubt the authenticity of the testimony quoted.

15 Kerensky, Russia, op. cit., pp. 87-90, 151. The details of Kerenskii's oral recollections were repeated to me by Utechin, Professor of History at the Pennsylvania State University, during numerous conversations between 1970 and 1982.

16 V. D. Nabokov, "Vremennoe pravitel'stvo", in: Arkhiv Russkoi Revoliutsii, I (1921), p. 15 (written in 1918); Mel'gunov, Vospominaniia i dnevniki, op. cit., I, pp. 142-46 (written in 1920); V. D. Bonch-Bruevich, "Moi vospominaniia o P. A. Kropotkine", in: Zvezda, 1930, No 4, pp. 182-83; I. V. Gessen, "V dvukh vekakh: Zhiznennyi otchet", in: Arkhiv Russkoi Revoliutsii, XXII (1937), pp. 216-18, 366; P. N. Miliukov, Vospominaniia (1859-1917) (2 vols; New York, 1955), II, pp. 311-12, 332-33 (written during 1940-43). It should be noted that the references to political Masonry in Nina Berberova's The Italics Are Mine (New York, 1969), pp. 311-15, are based on second-hand information and either inaccurrate or irrelevant. 
century. ${ }^{17}$ Yet there exists some evidence that the organization actually emerged before that, possibly as early as 1901 or 1902 . Thus Kuskova, who was one of its founders, maintains that the political Masonic organization originated just after the turn of the century, and that it was created by the same individuals who subsequently founded the Union of Liberation (Soiuz osvobozhdeniia), the organization of Russian liberals and radicals which was instrumental in bringing about the 1905 Revolution. ${ }^{18}$ According to Kuskova, in addition to herself and her husband, S. N. Prokopovich, the founding members of political Masonry included the radicals $\mathrm{N}$. A. Berdiaev, S. N. Bulgakov, S. L. Frank, B. A. Kistiakovskii, P. B. Struve and V. V. Vodovozov, as well as the liberals Prince Petr D. Dolgorukov, I. M. Grevs, S. A. Kotliarevskii, N. N. Kovalevskii, N. N. L'vov, P. I. Novgorodtsev, I. I. Petrunkevich, A. S. Petrunkevich, P. I. Rodichev, Prince D. I. Shakhovskoi, V. I. Vernadskii and D. E. Zhukovskii. ${ }^{19}$ While Kuskova's memory for details is often quite unreliable - and these recollections were written when she was already in her eighties - , it seems unlikely that she should simply have invented the whole business. Moreover, Obolenskii, who joined political Masonry in 1910, implies that the organization originated shortly after the turn of the century, while Kerenskii, a political Mason since 1912, accepted Kuskova's account apparently without reservations. ${ }^{20}$ At the same time, however, Kuskova herself has written elsewhere that political Masonry "was begun after the destruction of the revolution of 1905, in the time of savage repressions", and that it "functioned from 1907-08".21 Still, this contradiction in her testimony may be more apparent than real. For according to Kerenskii, whose source was most certainly Kuskova, sometime toward the end of 1905, when political parties became legal in Russia, the Masons dispersed, to be re-united once

17 Utechin is alone in suggesting that a political Masonic organization had existed earlier, Russian Political Thought, op. cit., p. 110.

18 Kuskova to Dan, November 14, 1958.

19 Personal communication to the author from Utechin, who reports that in 1958 Kuskova wrote to Kerenskii that if he wished to know the names of the founders of the political Masonic organization he should consult the list of founders of the Union of Liberation in G. Fischer's Russian Liberalism: From Gentry to Intelligentsia (Cambridge, Mass., 1957), pp. 140-41. In her letter, which Utechin read, Kuskova asserted that she had given Fischer the list without telling him that the Liberationists were also political Masons. However, Fischer states that his list came from I. I. Petrunkevich's memoirs. I have not been able to clarify this matter.

${ }^{20}$ Obolenskii, quoted loc. cit., p. 606; Kerensky, Russia, pp. 87-88. Since Kerenskii joined the organization only in 1912, what he knew of its origins he learned from Kuskova. Personal communication from Utechin to the author.

${ }^{21}$ Kuskova to Vol'skii, November 10, 1955; id. to Abramovich, December 2, 1952 , Nicolaevsky Collection, uncatalogued. 
it became clear that their aims could not be achieved through legal and open means alone. ${ }^{22}$ Thus Kuskova may simply have been referring to different stages in the organization's history. While any final conclusions about its origins must await further evidence, it does appear likely that the political Masonic organization may have existed, if only in embryonic form, already at the beginning of the century.

If the origins of Russian political Masonry remain shrouded in mystery, the reasons for its existence and the goal which it set itself do not. According to Kuskova, its founders felt that political parties, because of their narrow partisanship, were inadequate to effect the political changes desired by the oppositional movement. It was thought, therefore, that a looser, non-partisan form of organization would have a broader appeal, would be better able to articulate public opinion and hence be a more effective political weapon. ${ }^{23}$ Thus the political Masonic organization - "created I) for Russian raw material (syr'e) who feared parties [and] 2) for highly placed persons who did not want to associate with "plebs" - was intended to be a rallying point for all progressive, democratically-minded, elements of Russian "society" (obshchestvo); it was to provide a "certain community - without classes and for a single task". ${ }^{24}$ The task, in Kerenskii's words, was "the establishment in Russia of a democracy based on broad social reforms and on a federal state order". ${ }^{25}$ No doubt many Masons would have preferred to pursue this aim openly and legally, but Russian political conditions simply did not permit it. Not only government repression, but also public opinion militated against the open association of politically diverse elements united for a common goal. ${ }^{26}$

Whether or not political Masonry originated as early as 1901-02, a question immediately arises regarding its relationship to traditional Freemasonry, illegal in Russia since 1822 , but revived on the eve of the 1905 Revolution. ${ }^{27}$ Several of those whom Kuskova indicates as founders of political Masonry are known to have been Freemasons. Prokopovich

22 Personal communication from Utechin.

23 Kuskova to Vol'skii, November 10, 1955; personal communication to the author from Utechin recalling Kerenskii's observations about the organization's aims.

24 Kuskova to Dan, February 5, 1957, Dan Archive XVI/13. The term "society" was used at the time to distinguish the educated, cultured element of the populace from the masses, or "the people" (narod).

25 Kerensky, Russia, p. 89.

${ }^{26}$ Ibid., p. 88. And in one of her letters, Kuskova expresses her regret that it had been necessary to lead a "double existence", but insists that "anything else was impossible". To Dan, February 5, 1957.

${ }^{27}$ See B. Elkin, "Attempts to Revive Freemasonry in Russia", in: Slavonic and East European Review, XLIV (1966), pp. 454-72. 
had joined a Belgian lodge while abroad at the end of the 1890 's; ${ }^{28}$ Shakhovskoi and Kotliarevskii were active in the re-establishment of Russian Freemasonic lodges, under the auspices of the Grand Orient de France, during 1904-06.29 There are several difficulties, however, with concluding from this that Freemasonry and political Masonry were one and the same. One of these is the fact that traditional Freemasonic societies did not admit women. Another is Kuskova's assertion that political Masonry never had any connections with foreign Freemasonry (zagranichnoe masonstvo). ${ }^{30}$ Yet the evidence at hand does not support the view that initially there were two wholly separate organizations. Indeed, Obolenskii and Kerenskii clearly suggest early links between political Masonry and Freemasonry. ${ }^{31}$ Moreover, Nekrasov states explicitly that in 1908 he entered a St Petersburg lodge which "belonged to the political branch of Freemasonry" ${ }^{32}$ That lodge was undoubtedly Polar Star (Poliarnaia zvezda), the membership of which included such prominent political figures as the Progressists (members of the Progressive Party) N. A. Morozov and Count A. A. Orlov-Davydov; the Kadets S. A. Balavinskii, Prince D. O. Bebutov, A. M. Koliubakin, V. A. Maklakov, M. S. Margulies and A. I. Shingarev; the Trudoviks A. I. Braudo and P. N. Pereverzev; and the non-party socialist L. I. Lutugin. ${ }^{33}$

It would seem, therefore, that by 1908 , if not earlier, political Masonry constituted a special branch of Freemasonry, one in which women may have been adjunct or even full members. It is possible, of course, that there were additional political Masonic lodges which maintained a separate existence, and that it was only these which admitted women.${ }^{34}$ In any case, Kuskova's assertion that political Masonry never had any ties with foreign lodges can be explained by the fact that, soon after the Russian Freemasonic lodges received official recognition from the Grand Orient de France in 1908, they immediately formed their own organization, Masonry of the Peoples of Russia (Masonstvo narodov Rossii), and by 1910 had severed

28 N. V. Vol'skii to B. I. Nikolaevskii, March 8, 1960, Nicolaevsky Collection, uncatalogued; Nikolaevskii to Vol'skii, March 4 and April 3, 1960.

29 Gessen, "V dvukh vekakh", loc. cit., pp. 216-17; Elkin, "Attempts", loc. cit., p. 467. It may be noted also that at least some people at the time thought that Struve, too, had Freemasonic connections. Bonch-Bruevich, "Moi vospominaniia", loc. cit., p. 183.

30 Kuskova to Vol'skii, November 10, 1955.

31 Smith, "The Role of Russian Freemasonry", p. 605; Kerensky, Russia, pp. 87-88.

32 Nekrasov, quoted in Iakovlev, 1 avgusta 1914, p. 230.

33 Membership lists are provided in Elkin, "Attempts", p. 468.

34 Such seems to be Elkin's conclusion, but he provides no evidence to support his contention that in 1906-08 "There were [. . . ] secret political associations which called themselves masonic but apart from an oath had nothing in common with [Free]masonry." Ibid., p. 472. 
all ties with their French sponsor. "In 1909", recalls Nekrasov, "to cleanse the new organization of dangerous [...] and simply morally unscrupulous people, the organization was declared dissolved and resumed its work now without these elements [...]. The new organization was strictly conspiratorial". ${ }^{35}$ Not only did Masonry of the Peoples of Russia resume its activities in 1910 without such suspect individuals as Bebutov and Margulies, but also without Balabinskii, Maklakov, and probably some others who did not wish to end their association with French Freemasonry. ${ }^{36}$

The political Masonry which functioned after 1910 was, in Kerenskii's words, "an irregular Masonic organization. First of all, it was unusual in that it had severed ties with all foreign societies and accepted women for membership. Furthermore, the complex ritual and the Masonic system of degrees were abolished, and only that essential inner discipline was maintained which would ensure the moral qualifications of the members and their ability to maintain secrecy." ${ }^{37}$ Yet while Masonry of the Peoples of Russia had no connections with Freemasonry, it apparently did retain the organizational structure of the Grand Orient de France in its new statutes. ${ }^{38}$ The basic unit of the new political Masonry was the local territorial lodge, but there were also special lodges within various public organizations and government institutions. Each lodge consisted of a small number of people (five, according to Kuskova; ten to twelve, according to Nekrasov) and was headed by a chairman. 39 "At its inception", Kerenskii recalls, "each lodge became an autonomous unit. Other organs had no right to interfere with the work or election of members." By 1912, if not earlier, elected delegates from the lodges were meeting annually in regional

35 Quoted loc. cit. Chkheidze and Gal'pern, or perhaps Nikolaevskii, referred to the new organization as the Supreme Council of the Peoples of Russia (Velikii sovet narodov Rossii), Haimson, "The Problem of Social Stability", p. 14. However, this is most likely a conflation of the names of the organization and its executive organ. see below.

36 Nekrasov, quoted loc. cit.; Kuskova to Vol'skii, November 10, 1955. Mel'gunov, Na putiakh k dvortsovomy perevorotu, pp. 182-83, thinks that Bebutov's exposure as a police informer was probably responsible for the decision to dissolve the old organization. He erroneously refers to Polar Star as Northern Star (Severnaia zvezda).

${ }_{37}$ Kerensky, Russia, p. 88. A very similar description of the organization is provided in Kuskova to Vol'skii, November 10, 1955.

${ }^{38}$ Nekrasov, quoted loc. cit., states that the statutes were published "in cypher ( $z a$ shifrovan)" in a work entitled Ital'ianskie ugol'shchiki 18 stoletiia, published by the St Petersburg firm of Semenov. In fact, the work is E. Sidorenko's Ital'ianskie ugol'shchiki nachala XIX veka (St Petersburg, 1913), which contains selections from the statutes of the Grand Orient de France.

39 Kuskova to Vol'skii, November 10, 1955; Nekrasov, quoted loc. cit. Paragraph 12 of the statutes of the Grand Orient specifies a lodge membership of seven to fourteen, Sidorenko, Ital'ianskie ugol'shchiki, op. cit.. p. 131. Regarding the nature of the lodges, see also Kerensky, Russia, p. 89. 
and national conventions at which they discussed their work and selected the organization's executive bodies. ${ }^{40}$

The national executive body, the Supreme Council (Verkhovnyi sovet), was elected indirectly: the delegates to the national, All-Russian convention elected from its ranks by secret ballot three electors, who then secretly chose the members of the Supreme Council from among the organization's general membership. The identity of those selected to sit on the Council remained secret; their names were not divulged to the membership at large or even to the convention delegates. ${ }^{41}$ If the political Masons continued to adhere strictly to the procedures of the Grand Orient de France - and since the organizational structure remained the same, it seems likely that they did - , the convention's electors chose only three members of the Supreme Council; these in turn selected three others. This six-member Council could then continue to co-opt up to five additional members; the total membership was not to exceed eleven. The Supreme Council served a one-year term, which could be renewed with the approval of the next national convention. ${ }^{42}$ As the highest executive body of political Masonry, the Council was responsible for formulating policy and co-ordinating the activities of the entire organization. Through its secretary, who alone was known to all lodge chairmen and through whom it communicated with the other organs, the Supreme Council submitted an annual progress report to the All-Russian convention, in which it "assessed the political situation, and proposed the program for the year ahead". ${ }^{43}$ This program provided the lodges with guidelines for political action, although it was apparently up to each lodge to decide how these guidelines would be implemented.

Political Masonry recruited its members from among the most prominent representatives of Russian "society". Political parties of the center and left, learned and professional societies such as the Imperial Free Economic Society (Imperatorskoe vol'no-ekonomicheskoe obshchestvo), the Technical Society (Tekhnickeskoe obshchestvo), the teachers' and writers' organizations, and the co-operatives, as well as government institutions like the zemstvos (local institutions of self-government), the city dumas (councils), the State Duma, and even the military were all recruiting grounds for the political Masonic organization. ${ }^{44}$ Nekrasov recalls that

40 Kerensky, loc. cit. Also see Obolenskii's testimony, quoted loc. cit. Haimson's information that only three conventions were held before the 1917 revolutions - in 1912, 1914 and 1916 - is puzzling. "The Problem of Social Stability", p. 14.

41 Nekrasov, quoted loc. cit.; Obolenskii, quoted loc. cit.

42 Such, at least. is the procedure specified in Paragraphs 28-30 of the statutes of the Grand Orient de France, Sidorenko, Ital'ianskie ugol'shchiki, pp. 136-37.

43 Kerensky, loc. cit.

44 Kuskova to Vol'skii, November 10, 1955; Kerensky, loc. cit. 
"the organization did not strive for numbers, but selected people morally and politically pure, and most of all, [people] who enjoyed political influence and authority." 45 Obolenskii, too, emphasizes that "Russian masonry recruited primarily significant people, known for their influence in various circles of Russian progressive society", while Kuskova notes that it was "One of the rules: not to approach for membership people who seemed unstable in their moral or political nature. Many candidates [...] were rejected."46

How large the political Masonic organization actually became is difficult to determine precisely. By 1914, and perhaps earlier, there were lodges not only in St Petersburg and Moscow, but also in many provincial cities, including Kiev, Samara, Saratov, Tiflis and Kutais. ${ }^{47}$ Kuskova has described the organization as "enormous", maintaining that "by the February Revolution all Russia was covered by lodges". ${ }^{8}$ While this may be something of an exaggeration, the network was certainly extensive. According to Nekrasov, secretary of the Supreme Council from 1910 to 1913 and again from mid 1914 to mid 1916, "by the time of the February Revolution Masonry had 300-350 members in all". ${ }^{49}$ Who were these Masons? Unfortunately, those who broke their silence about the organization were particularly reticent about revealing the names of other participants. Nevertheless, sufficient direct evidence is available to establish with confidence the identities of a number of individuals who were active in political Masonry after 1910, if not earlier. Among them are representatives of various political parties from the Octobrists to the Bolsheviks, as well as a number of influential non-party people. ${ }^{50}$ Russian liberals participating in the political Masonic organization, in addition to the Kadets Obolenskii and Nekrasov and to Velikhov, included: 1) the Octobrist A. I. Guchkov; 2) the Progressists I. N. Efremov, A. I. Konovalov, Savva Morozov and Count Orlov-Davydov; 3) the Kadets D. N.

\footnotetext{
45 Nekrasov, quoted loc. cit.

46 Obolenskii. quoted loc. cit., p. 607: Kuskova to Vol'skii, November 10, 1955.

${ }^{47}$ From the testimony of Chkheidze and Gal'pern in Haimson. "The Problem of Social Stability", p. 14. See also Kuskova to Dan, February 5, 1957.

${ }^{48}$ Kuskova to Vol'skii, November 10, 1955. See also id. to Dan. March 29, 1954, Dan Archive XIV/10.

49 Quoted loc. cit., pp. 230-31.

50 The following list is compiled from the testimony in Haimson, "The Problem of Social Stability", p. 14; Iakovlev, 1 avgusta 1914, pp. 231, 234; Obolenskii, quoted loc. cit., p. 606: Kuskova to Dan, February 12 and June 6, 1957, Dan Archive XVI/13, November 14, 1958; id. to Vol'skii, November 10, 1955, February 26, 1956; Nikolaevskii to Vol'skii, April 3, 1960. In addition the names of V. la. Bogucharskii, L. M. Bramson, S. A. Kotliarevskii, P. I. Pal'chinskii and I. I. Skvortsov-Stepanov were supplied by Utechin from his conversations with Kerenskii. Personal communication to the author.
} 
Grigorovich-Barskii, Grushevskii, Koliubakin (who was secretary of the Supreme Council from mid 1913 to mid 1914), L. V. Pisarzhevskii, Baron F. R. Shteingel', V. A. Stepanov, M. I. Tereshchenko, N. P. Vasilenko and N. K. Volkov; and 4) the non-party liberals V. I. Bauman and Kotliarevskii. In addition to the Trudovik Kerenskii (who served as secretary of the Supreme Council from mid 1916 on), the Mensheviks Chkheidze and Gal'pern, and the non-party socialists Kuskova and Prokopovich, radicals who took part in the political Masonic organization after 1910 included: 1) the Popular Socialist A. A. Dem'ianov; 2) the Trudoviks L. M. Bramson and Pereverzev; 3) the Socialist Revolutionaries B. V. Savinkov and Sidamon-Eristov; 4) the Mensheviks A. I. Chkhenkeli, E. P. Gegechkori and M. I. Skobelev; 5) the Bolsheviks S. P. Sereda and I. I. Skvortsov-Stepanov, ${ }^{51}$ and 6) the non-party socialists M. A. Aldanov, V. Ia. Bogucharskii, Lutugin and P. I. Pal'chinskii. In view of the persistence of the myth of a Jewish-Masonic conspiracy in Russian politics on the eve of 1917 , it is worth noting that there were very few Jews among the political Masons. ${ }^{52}$

Relatively little is known about the specific activities of Masonry of the Peoples of Russia. The sources at hand reveal almost nothing about the pre-war years, and they provide only limited, and for the most part indirect, information about the period after 1914. The organization's strategy is clear enough: "to restore the Union of Liberation and to work underground for the liberation of Russia", ${ }^{3}$ taking care "not to repeat [...] the mistakes of 1905 when the progressive forces split and the Tsarist government easily crushed them one by one". ${ }^{54}$ The Masons' primary task, as Kuskova saw it, was to attract Russia's large apolitical majority to the ranks of the oppositional movement. This they did by utilizing the legal cover of the public organizations and government institutions which they had penetrated. ${ }^{55}$ At the same time the political Masonic organization sought to establish itself as the co-ordinating center for the entire oppositional movement. To this end, in early 1914 Moscow Masons Konovalov, Morozov, Nekrasov, Prokopovich, Skvortsov-Stepanov and Volkov created the so-called Information Committee (Informatsionnyi komitet), a

51 There appear to have been only a few Bolsheviks associated with political Masonry. Obolenskii, quoted loc. cit., p. 607 , says that he knew of only one minor party figure who belonged to the Masonic organization. Kuskova says there were two or three, to Vol'skii, November 10, 1955; to Dan, March 29, 1954.

52 See Obolenskii's discussion of the matter, loc. cit.

53 Kuskova to Vol'skii, November 10, 1955.

54 Nekrasov, quoted loc. cit.

55 Kuskova to Dan, February 12, 1957. 
front organization to provide closer contacts between liberal and socialist parties. From the police reports about the Moscow political scene it is clear that the Information Committee was intended as a preliminary step toward the formation of a broad united front of all oppositional parties. ${ }^{56}$

The Masons' efforts to establish a wide democratic front intensified with the outbreak of the First World War. In early September 1914 Kerenskii and others attempted to organize a union of non-party radical intelligentsia in Petrograd. That fall Masons from Moscow and Petrograd began traveling throughout the country to take the public pulse and to garner support for a united opposition. ${ }^{57}$ However, the war also brought certain changes in the Masons' strategy. "With the outbreak of World War I", writes Kerenskii, "our program had to be revised. [...] If final victory was to be achieved, it was essential to effect a reconciliation between all classes of society, and between the people and the supreme power. [...] The unconditional defense of our country remained the basis for our work until the end." 58 And Obolenskii recalls: "Among the Masons were, of course, people who desired revolution and who carried on revolutionary propaganda, but there were also many opponents [of revolution]. The majority, to which I belonged, in any case rejected revolution during wartime." ${ }^{59}$ Hence the political Masonic goal of establishing democracy in Russia was temporarily subordinated to the task of defending the country. Specifically this was to mean preventing a popular uprising.

By early 1915 the Masons seem to have become increasingly alarmed about the government's apparent inability to prosecute the war successfully, and the consequent growing threat of popular revolution. It was apparently this concern that led them to continue their attempts to organize the Russian intelligentsia in non-party unions. ${ }^{60}$ It was this

\footnotetext{
56 Police agent's report of February 1, 1914, cited in Chermenskii, IV Gosudarstvennaia duma, op. cit., pp. 54-55; circular from the Director of the Department of Police, May 13, 1914, reproduced in I. A. Menitskii, Revoliutsionnoe dvizhenie voennykh godov, 1914-1917 (2 vols; Moscow, 1924-25), I, pp. 408-09. See also Haimson, "The Problem of Social Stability", pp. 4-8, 14. The fact that the Progressist P. P. Riabushinskii and the Menshevik A. M. Nikitin were also members of the Committee would suggest that they, too, were Masons. See Chermenskii, loc. cit., where it is also stated that the Progressist N. D. Morozov was a member of the Committee (although it may be Savva Morozov who is meant). The police, it should be pointed out, had no suspicions that the Committee had any links with political Masonry.

57 See D. F. Sverchkov, Kerenskii, 2nd ed. (Leningrad, 1927), p. 10; Kuskova to Dan, March 29, 1954.

58 Kerensky, Russia, p. 90.

59 Quoted loc. cit.

60 On the efforts of Kerenskii and others in Moscow, see report of the Moscow Okhrana Chief, May 16, 1915, reproduced in Menitskii, Revoliutsionnoe dvizhenie, op. cit., I, p.
} 
concern, too, which prompted the political Masonic organization to launch the effort that, according to Kerenskii, eventually resulted in the formation of the Progressive Bloc, the Duma alliance of Octobrists, Progressists and Kadets created that summer to pressure the Emperor into granting a "government of public confidence". ${ }^{61}$ At the same time, police reports indicate, Kuskova and Prokopovich actively, if ultimately unsuccessfully, worked to establish some sort of agreement between the Kadets and parties further left. ${ }^{62}$ And Velikhov recalls that when he joined the political Masonic organization during the Fourth Duma, the organization's main goal was the creation of "a bloc of all oppositional parties of the Duma" ${ }^{63}$ Perhaps it was the Masons' failure to achieve this broader coalition which now led some of them to adopt more extreme tactics. In any case, what was certainly another Masonic front organization, the Committee of Public Safety (Komitet narodnogo spaseniia), was created in Moscow in late summer of 1915. The Committee's "Disposition No I", composed in early September, articulated the view that Russia was engaged in a two-front war, fighting for her survival against an internal enemy, i.e., the existing regime, as well as against a foreign enemy, and that the only way to ensure victory over the latter was through a victory over the former. In accordance with the Masons' desire to avoid a popular uprising, the Committee emphasized that the struggle against the government must be a peaceful and orderly one. Kerenskii and Guchkov, along with non-party liberal Prince G. E. L'vov, were designated as the leadership core of this struggle. ${ }^{64}$ Whether or not "Disposition No l" represented the views of the political Masonic organization as a whole, the existence of the Committee of Public Safety was a clear indication of the Masons' mounting concern over the regime's conduct of the war and of their conviction that the present government was unable to win that struggle.

415; Sverchkov, Kerenskii, op. cit., p. 10. Among those joining Kerenskii in the Moscow effort was Prince Shakhovskoi, one of those named by Kuskova as a founder of political Masonry. This and other indirect evidence (see below) leaves little doubt that Shakhovskoi was an active member of Masonry of the Peoples of Russia.

61 Kerenskii told Utechin that political Masonry had provided the inspiration for the creation of the Progressive Bloc. Personal communication to the author from Utechin.

62 Report of the Moscow Okhrana Chief, August 24, 1915, reproduced in Menitskii. Revoliutsionnoe dvizhenie, I, p. 427. It should be noted that in reporting on the activities of Kuskova, Prokopovich and others in Moscow the police remained unaware of the critical Masonic connection.

63 Quoted in Iakovlev, l avgusta 1914, p. 234. My emphasis.

64 "Disposition No 1", in: Krasnyi Arkhiv, XXVI (1928), pp. 212-13. Regarding the provenance of this document, see Katkov, Russia 1917: The February Revolution, op. cit., pp. 165-66. While it is likely that L'vov, too, was a Mason, there is no direct evidence of this in the available sources. 
In the early spring of 1916 the political Masonic organization joined the growing number of oppositional groups which, following the breakdown of negotiations between the government and the Progressive Bloc, had begun to draw up lists of candidates for a responsible Ministry. At the beginning of April, at what Kuskova describes as a Masonic-sponsored meeting in her Moscow apartment, she and Prokopovich along with Shakhovskoi, Lutugin, Skvortsov-Stepanov and others compiled a list of Ministers acceptable to them. This list, which Kuskova provides in two variants, designated the non-party liberal Prince L'vov as Premier, the Kadet leader Miliukov or Prince G. N. Trubetskoi as Minister of Foreign Affairs, Konovalov or the non-party liberal S. N. Tret'iakov as Minister of Trade and Industry, the Kadet A. I. Shingarev as Minister of Agriculture, Guchkov as Minister of War, the Kadets P. V. Gerasimov or A. A. Manuilov as Minister of Education, the Kadet lawyers V. A. Maklakov or V. D. Nabokov as Minister of Justice, and the socialist Lutugin as Minister of Labor. ${ }^{65}$ While Kuskova exaggerates slightly in asserting that "in February this list was implemented in fact with very few changes", it is true that many of those named did actually participate in the Provisional Government. ${ }^{66}$ But regardless of whether the composition of the future government was first worked out at the Masons' April meeting, as she claims, it is clear that by February 1917 the political Masonic organization had indeed formulated a list from which some, if not all, of the new Cabinet would be drawn. Miliukov, who played a major role in the final selection of the government, recalls: "It was most difficult of all to recommend the unknown novice in our midst, Tereshchenko [. . .]. In what 'list' did he 'enter' the Ministry of Finance? I did not know then that the source was the same as that from which Kerenskii was imposed, from which stemmed the republicanism of our Nekrasov, and from which the unexpected radicalism of the 'Progressists', Konovalov and Efremov, originated", i.e., from the political Masonic list. ${ }^{67}$

65 One variant of Kuskova's list is found in her letter to Mel'gunov, cf. note 13. The other is in Miliukov, Vospominaniia, op. cit., II, pp. 273-74, and is apparently also taken from a letter. That this meeting, called by Prince Shakhovskoi, was Masonic-inspired is clear from Kuskova to Dan, February 21, 1956, Dan Archive XV/12.

${ }^{66}$ E. D. Kuskova, "Vnutrennii krizis", in: Novoe Russkoe Slovo, November 4, 1953. The lists compiled by other groups and the final composition of the Provisional Government can be found in Hasegawa, The February Revolution, p. 523.

67 Miliukov, Vospominaniia, II, pp. 311-12. A subsequent passage leaves no doubt that Miliukov was referring to a Masonic list, ibid., p. 333. Miliukov maintains that he learned about the existence of the political Masonic organization, which he does not mention by name, only long after the events he is describing. However, Kuskova insists that because of his political importance the Kadet leader was kept informed of the organization's 
That not all Masons were content merely to put pressure on the regime is evident from the fact that several of them took part in the so-called "Guchkov plot", one of the two main anti-government conspiracies which developed during the course of 1916. Guchkov's scheme, in which Nekrasov, Tereshchenko, Konovalov and Efremov were also involved, consisted of a plan to kidnap the Tsar, force his abdication and name a new government. ${ }^{68}$ However, there is no firm evidence that this was a Masonic-inspired conspiracy, that it had the official sanction of the political Masonic organization. Indeed, the evidence at hand indicates quite the opposite. Thus Kuskova recalls that Guchkov's plan "was sharply condemned by members of Masonry", while Kerenskii, secretary of the Supreme Council by the summer of 1916, maintains that although the Masonic leaders were aware of the plot they did not know all the details. ${ }^{69}$ It seems then that the majority of Masons remained opposed to any kind of revolutionary action during wartime. Nevertheless, the political Masonic organization was apparently willing to take advantage of whatever might result from Guchkov's scheme. Kerenskii writes: "We leaders of the Masonic organization [...] made preparations for the decisive moment. These preparations were concluded with the setting up of an information office of the left-wing parties for the purpose of preparing the people to receive the results of the coup d'état, step by step, and to encourage them to give it their support, or in any event to take no action against it." The purpose of this information bureau, he notes elsewhere, was "contrôler au besoin les excès de la populace". ${ }^{70}$ There is ample evidence that throughout 1916 Masonic activity continued to be motivated primarily by fear of what a popular revolution would mean for the war effort. V. B. Stankevich, former staff officer for the Provisional Government, remembering an encounter with Kerenskii and others on the eve of the February Revolution, notes in his memoirs that "Everybody definitely disapproved of the possibility of popular action, fearing that once roused a popular mass movement can find itself in extreme left channels and this

major decisions and even occasionly availed himself of its services. To Vol'skii, November 10, 1955; to Dan, February 14, 1956. This is consistent with Obolenskii's claim, loc. cit., that Miliukov "not only did not participate in the Russian masonic movement but had a negative attitude toward it." For Miliukov may have disapproved of political Masonry and still have utilized the organization when it was politically useful to do so.

68 See "Iz vospominanii A. I. Guchkova", in: Poslednie Novosti (Paris), August and September 1936. It should be noted that nowhere does Guchkov allude to the existence of the political Masonic organization.

69 Kuskova to Vol'skii, November 10, 1955; Kerensky, Russia, p. 151.

70 Kerensky, loc. cit.; id., La Révolution russe 1917 (Paris, 1928), p. 109. 
will create extraordinary difficulties in the conduct of the war."71 And there can be little doubt that when popular discontent began to erupt in late February the Masons' overriding concern was to contain it.

Precisely what role the political Masonic organization played in the February Revolution has still to be determined. Obolenskii, who had served as a member of the Supreme Council for three years, writes: "Not long before the revolution I left the Supreme Council, and for this reason its activity during the revolution is not known to me. However, knowing its approximate composition I cannot imagine that it played a large role in revolutionary events because its members came from various mutually hostile political parties whose internal cohesion was very much stronger than Masonic "fraternity.."72 Similarly, noting that some people "attributed the fall of the monarchy and the formation of the Provisional Government to the secret activity of the [political Masonic] lodges", Kerenskii felt it his duty "to refute this absurd interpretation". ${ }^{73}$ Nekrasov and Kuskova have rather different estimates of the Masonic contribution to the February Revolution, however. Nekrasov contends that "Masonry played a certain role both in the period of preparation of the February Revolution, when it was a distinctive (svoeobraznyi) conspiratorial center of the 'popular front', and in the first days of the February Revolution, when it assisted the unification of progressive forces under the banner of revolution."74 And Kuskova goes even further, insisting that "Really and truly we [Masons] made the whole revolution." 75 While Kuskova's claim may be an overstatement, the evidence at hand clearly supports the view that the political Masonic organization contributed significantly to the overthrow of the Monarchy and to the formation of a democratically oriented government in Russia.

The attitude of the Russian high command was of critical importance in determining the outcome of the February events. For without the support of the military the revolution could not have succeeded. While firm evidence must still be forthcoming, it nevertheless seems likely that it was sympathy with the aims of political Masonry, if not actual membership in the organization, which made at least some members of the high command receptive to the idea of the Tsar's abdication. There is ample evidence that the Masons made a concerted effort to win the support of Russia's military

71 V. B. Stankevich, Vospominaniia 1914-1919 g. (Berlin, 1920), p. 65. Cf. Obolenskii's statement, cited above, p. 251, about the majority of Masons being opposed to revolution during wartime.

72 Quoted loc. cit.

73 Kerensky, Russia, p. 88.

74 Quoted loc. cit., p. 231.

${ }^{75}$ Kuskova to Dan, February 5, 1957. 
leaders for a democratic regime. General A. M. Krymov, commander of the Third Cavalry Corps and a participant in Guchkov's plot, and General A. A. Manikovskii, future Deputy Minister of War in the Provisional Government, were two of those with whom "an organizational connection was established". ${ }^{76}$ More importantly, Chief of Staff General M. V. Alekseev, who was responsible for the military pressure which ultimately persuaded Nicholas II to give up the crown, was in close contact with several leading Masons in this critical period. ${ }^{77}$ But whether or not the political Masonic organization was instrumental in forcing the abdication and the ensuing events, ${ }^{78}$ there can be little doubt that Masonry exerted a major influence on the selection of the new government and the formulation of its program. Thus Nekrasov writes: "In all negotiations about the organization of authority the Masons played a behind-the-scenes but prominent role." 79 Evidence of this is to be found in the previously cited testimony of Miliukov regarding the composition of the new government, as well as in that of Nabokov, who observes in his memoirs that only later did he understand the surprising make-up of the Cabinet ${ }^{80}$ Finally, it can hardly have been mere coincidence that at least six of the twelve men originally selected for Ministerial posts - Guchkov, Konovalov, Nekrasov, Tereshchenko, Kerenskii and Chkheidze - were Masons. ${ }^{81}$ It may well be

${ }^{76}$ Nekrasov, quoted loc. cit. It is interesting to note that in February 1917 it was Manikovskii whom Nekrasov put forward as the man best suited to head a military dictatorship in Russia. Minutes of the February 27 Duma meeting, reproduced in The Russian Provisional Government, 1917: Documents, ed. by R. P. Browder and A. F. Kerensky (3 vols; Stanford, 1961), I, p. 45.

77 On Alekseev's political connections with Konovalov and Guchkov, see the testimony of journalist M. K. Lemke which is summarized in Katkov, Russia 1917: The February Revolution, p. 40. After the February Revolution General Alekseev became Supreme Commander of the Provisional Government's forces. Following Guchkov's resignation as Minister of War in May, the General suggested that either Kerenskii or Pal'chinskii, an engineer and like Kerenskii not a military man, should assume the vacated post. Kerensky, Russia, p. 266, note. While there is no direct evidence, it is difficult to escape the conclusion that Alekseev was probably a Mason.

${ }^{78}$ In this connection it is not insignificant that Pal'chinskii, the Mason who served as secretary of the Military Commission formed on February 27, was among those responsible for preventing the Tsar from returning to the capital and, hence, from obtaining assistance in his plight. For this information I am indebted to Hasegawa, who was able to examine Pal'chinskii's papers and the records of the Military Commission which are preserved in Soviet archives.

79 Quoted loc. cit., p. 232.

80 For Miliukov's testimony, written in the 1940's, see above, p. 253. Nabokov's allusion to the Masons was written in early 1918, cf. note 16.

81 Chkheidze was offered the post of Minister of Labor but turned it down, preferring to remain chairman of the Petrograd Soviet. P. N. Miliukov, Istoriia russkoi revoliutsii (3 vols; Sofia, 1921-32), I, p. 45. 
that it was political Masonic involvement in the February events which accounts in large part for the remarkably peaceful and orderly transition of power. As for the program of the new government, Kerenskii, its first Minister of Justice and later Premier, maintains that it was the democratic program formulated earlier by the political Masonic organization "which was implemented on a broad base by the Provisional Government". 82 Certainly the very substantial body of legislation passed during the government's brief existence strongly suggests that much of that legislation had been thoroughly worked out in advance.

The fate of political Masonry after February 1917 remains as obscure as its origins, and once again the available evidence is incomplete and contradictory. Nekrasov states that while the organization collapsed from internal political and social differences, its official dissolution was in fact bogus and, following the pattern of 1909-10, staged to eliminate undesirable elements. This time it was the entire left wing of the organization which was purged as "the right wing continued to work". ${ }^{83}$ Others maintain, in contrast, that the political Masonic organization ceased to function altogether in the wake of the February Revolution. Thus, Kerenskii asserts that "After the February Revolution [...] political passions flared up, and nonpartisan cooperation became quite impossible." ${ }^{84}$ Similarly, Kuskova writes that "with the organization of the Provisional Government this [Masonic] organization ceased its activity. There was not a single convention and this organization exerted no 'pressure' whatsoever on the decisions of the Provisional Government. Influence remained really only in personal connections." 85 Finally, Obolenskii, too, contends that political Masonry no longer functioned after February, and that "By the time of the Bolshevik Revolution and the Civil War, Russian masonry had ceased to exist in fact." 86

That the ranks of Masonry of the Peoples of Russia were split by political differences in the post-February period is clear. Yet, as Kuskova points out, personal if not organizational ties remained between political Masons of divergent ideological orientations. These ties must surely have facilitated the functioning of the Provisional Government, particularly in its experiment in "dual power" (dvoevlastie), i.e., the sharing of power with the

\footnotetext{
${ }^{82}$ Kerensky, Russia, p. 89. Kerenskii told Utechin that a good deal of the government's legislation had actually been worked out in advance by the Masons. Personal communication to the author from Utechin.

${ }_{83}$ Quoted loc. cit.

84 Kerensky, Russia, p. 90.

85 Kuskova to Dan, February 12, 1957.

86 Quoted loc. cit., pp. 607-08.
} 
Petrograd Soviet, whose leaders included Masons Kerenskii, Chkheidze and Skobelev. Moreover, Masonic ties between liberals and socialists were very likely significant, as well, in the creation of the Provisional Government's later coalition Ministries. ${ }^{87}$ But little can be said beyond this. As for political Masonry's fate after October, it is tempting to speculate that the Bolshevik seizure of power and the end of Russia's democratic government may have served to revitalize the organization. This would certainly make more comprehensible the émigré Masons' concern for colleagues still living in Russia, as well as their tenacious silence even about the origins and structure of an organization presumably long since defunct. Yet this, like so much else about political Masonry, must remain speculation until further evidence is forthcoming.

A quarter of a century ago Kuskova wrote of the Russian political Masonic organization that someday "Historians will know about all this." $88 \mathrm{Ob}$ viously that day has not yet come, for much has still to be learned about the organization's origins, structure, composition and activities. Nonetheless, as the foregoing has demonstrated, a good deal is known about political Masonry, and it should be clear that historians can no longer afford to ignore this aspect of Russian oppositional politics. While it is to be hoped that additional evidence will eventually emerge - indeed, Kuskova has held out the promise that she and Kerenskii have both left accounts of the organization in their respective archives ${ }^{89}$ - the information presently available to scholars is sufficient to warrant a re-examination of traditional notions about the oppositional movement in the early twentieth century. Certainly no analysis of the emergence of the movement for a united opposition during the First World War, of the fall of the Romanov dynasty or of Russia's brief experience with democracy in 1917 can be considered complete which does not take account of Russian political Masonry.

87 Very few historians have even suggested that Masonic connections might have had some significance in the post-February period. See Haimson, "The Problem of Social Stability", p. 15; Startsev, Revoliutsiia i vlast', p. 207; Katkov, Russia 1917: The Kornilov Affair, op. cit., pp. 57-59; Smith, "Masonic Movement in Russia after 1905", loc. cit., p. 132.

88 Kuskova to Dan, February 21, 1956.

89 Kuskova to Dan, February 6, 1956, January 20, 1957, Dan Archive XVI/13. Kuskova's papers remain under embargo until 1988 in the Bibliothèque Nationale. Kerenskii's papers, in the Humanities Research Center of the University of Texas at Austin, are now available to scholars, but a preliminary inquiry reveals nothing corresponding to the statement promised by Kuskova. 